\title{
Legal Protection of Debtor in Credit Settlement with Fiduciary Guarantee
}

\author{
I Gede Raka Ramanda,* Made Wiryani and Ni Luh Made Mahendrawati \\ Universitas Warmadewa, Denpasar-Bali, Indonesia \\ *Email: ramandaraka885@gmail.com
}

Published: 30/09/2021

How to cite (in APA style):

Ramanda, I, G, R., Wiryani, M., Mahendrawati, N, L, M. (2021). Legal Protection of Debtor in Credit Settlement with Fiduciary Guarantee. Jurnal Hukum Prasada, 8(2), 101-106. doi: https://doi.org/10.22225/jhp.8.2.2021.101-106

\begin{abstract}
This research is based on the provisions of law No. 42 of 1999 on fiduciary, in particular in article 34, and the provisions of article 27 paragraph 3 regulation of the Financial Services Authority No. 33/ POJK. 03/2018. There is a conflict of norms between debtors and creditors. The purpose of this study is to find out the legal consequences for debtors who have been voluntarily submitted to the creditor for a voluntary warranty and to find out the legal protection of a debtor who is in good faith hand over a fiduciary guarantee. The theory used in analyzing data is the theory of the Norms (Stufenbau Theorie), the theory of legal certainty and the legal protection theory. Meanwhile, the method used is normative research with a statutory approach. The result of this study showed that Financial Services Authority Regulation Number 33 /Pojk.03/2018 Regarding Quality of Earning Assets and Formation of Allowance for Earning Assets of Rural Credit Banks, regulating the issue of Collateral Foreclosed can be overridden or become not valid, or at least a material test by the Supreme Court. If violated, it results in being null and void. Furthermore, based on legal protection theory, that Article 15 paragraph (2) of Law Number 42 Year 1999 does not provide legal certainty and justice for debtors.
\end{abstract}

Keywords: good fait; supreme court; tort

\section{INTRODUCTION}

The function and role of the Bank as an intermediary institution in financial services is based on two interrelated elements namely Law and trust. A bank will be able to carry out its business activities normally if the public trusts or believes in placing its money. Public trust in the Bank will certainly be able to encourage the movement of funds from the community to be channelled back in the form of credit and provide banking services (Ibrahim, 2004:2). Provisions in Law No.42 of 1999 concerning Fiduciary, especially in Article 34 , that if there is a settlement of collateral that is bound in a fiduciary manner, an excess of sales of the debtor's obligations will be returned to the debtor, and vice versa, if the sales proceeds are less than debtor obligations, the creditor has the right to bill back to the debtor. While the provisions in article 27 paragraph 3 of the Financial Services Authority Regulation Number 33/Pojk.03/2018, that collateral that has been submitted to the creditor voluntarily or by auction, the debtor will get a Paid in Complete Statement. So with this statement, it gives the understanding that the debtor and creditor do not have rights or obligations anymore so that norm conflicts occur. In connection with the conflict of norms, the researcher wants to do further research, to find out the legal consequences for debtors who default on the settlement of fiduciary guarantees that have been voluntarily submitted to creditors who have received a Certificate of Settlement from Creditors and how the legal protection for debtors not able to fulfil its obligations as the agreement that was made 
previously (default) in good faith submit a guarantee that has been bound in a fiduciary manner.

Some similar related studies have been conducted previously about the legal protection of debtors in credit settlement with a fiduciary guarantee. Tahir (2017) in his study about Legal protection for creditors towards credit guarantee in Indonesia, showed that first, material objects guarantee is an absolute right over a particular object that is used temporarily if the debtor has broken the agreement. This material object can be used for the debt repayment of a debt. Second, material object guarantee (fiduciary objects) provides a special position to creditors, as it has preferential rights, namely the preference rights or droit de preference in making the settlement of receivables from the object which becomes objects guarantee. Ida et al. (2020) have also conducted a similar study that examined Legal Protection of Creditors and Debtors through Fiduciary Security Registration. The results of this study revealed that article 11 paragraph (1) of the Fiduciary Law can be effective if there is awareness from business actors about the importance of registration of fiduciary guarantees where legal protection will arise from registration and the absence of strict sanctions by imposing fines if not registered. Furthermore, another similar study has also been conducted by Puspasari \& Ngazis (2021) that examined Debtor Protection in the Execution of Fiducia Securities. The results of this study indicated that fairness in the credit agreement with the existence of standard clauses, namely that each party (creditors and debtors) must agree as stated in the Credit Agreement, namely through the fair and free exchange of performance implementation, because an unbalanced agreement will greatly harm one of the parties and therefore will very touching the sense of justice in society. The standard agreement made by the bank, apart from not contradicting the law, must also uphold the sense of justice and balance of the parties. Negotiations carried out in an agreement can also avoid one-sided contracts, and this is one of the first steps in creating a fair contract. Before signing the agreement, the parties should study in detail the clauses contained in the agreement, or at least find out the legal basis used in the event of undesirable things.

Based on the background and previous studies above, it can be assumed that the legal protection of debtors in credit settlement with a fiduciary guarantee needs to examine in depth. Hence, the purpose of this study is to find out the legal consequences for debtors who have been voluntarily submitted to the creditor for a voluntary warranty and to find out the legal protection of a debtor who is in good faith hand over a fiduciary guarantee.

\section{METHOD}

The method used in this study is the normative or doctrinal legal research method. This method is chosen because this study is categorized as a document study or the study is conducted in library research (Waluyo, 2008:13). Furthermore, this study also applied three kinds of approach, statutory approach, conceptual approach and case approach (Marzuki, 2009:93). In analyzing the data of this study, the theory used is the theory of the Norms (Stufenbau Theorie), the theory of legal certainty and the legal protection theory.

\section{DISCUSSION}

This study is conducted by focusing on the legal consequences for debtors who have been voluntarily submitted to the creditor for a voluntary warranty and the legal protection of a debtor who is in good faith hand over a fiduciary guarantee. Based on the data obtained, thus it can be analyzed and described the results in the following discussion.

\section{Legal Consequences for Debtors with Defaults to Fiduciary Collateral Settlement.}

Noting the provisions stipulated in the Regulation of the Financial Services Authority of the Republic of Indonesia Number 33 / Pojk.03/2018 Regarding the Quality of Earning Assets and the Forming of Allowance for the Elimination of Earning Assets of Rural Credit Banks, particularly regarding the requirements that must be met by Rural Credit Banks in determining Collateral Foreclosed, i.e. 1). Must be accompanied by a statement of the surrender of collateral or power of attorney to sell from the Debtor, 2). Statement of settlement from Rural Bank or creditor to Debtor. Thus, it can be stated that with the provision, that the Bank or the Rural Credit Bank as the creditor can take over the debtor's 
greatness that has been defaulted, with the conditions as mentioned above, then there will be legal consequences for both parties, both for the debtor and the creditor. The existence of collateral conditions taken over in the form of a Declaration of Submission of guarantees from the debtor and the Certificate of Settlement from the Creditor cause legal consequences, in the form of the abolition of the debtor's right to goods that are used as collateral and also write off debtors' obligations towards loan facilities received from creditors, because the issuance of a statement of repayment, can result in legal abolition of credit agreements, as principal agreements, meanwhile the fiduciary agreement is accessoire agreement (an additional agreement from a credit agreement). The legal consequences caused to the creditor can execute collateral that is carried out by the debtor voluntarily by selling it under the hand or by auction in public and taking repayment of the debtor's obligations towards the loan given by the creditor. If the sale proceeds less than the debtor's obligations, it will be a loss for the creditor, whereas if it is more and becomes a profit for the creditor. So the debtor is no longer entitled to the excess of the sale. Whereas based on the provisions in the Act Number 42 of 1999 concerning Fiduciary guarantees, Article 34 paragraph 3 and paragraph 4, stipulates that, in the event that the execution results exceed the guarantee value, the Fiduciary Recipient must return the excess to the Fiduciary Giver and if the execution results are insufficient for debt repayment, the debtor remains responsible for the outstanding debt. Furthermore, the provisions stipulated in Law Number 42 of 1999 concerning Fiduciary Guarantees and Provisions stipulated in Financial Services Authority Regulation Number 33 / Pojk.03/2018 Regarding Earning Asset Quality and Formation of Allowance for Earning Off Earning Assets of Rural Credit Banks, occurred norm conflicts, i.e. there are conflicting regulators that differ from one another. So it does not provide legal certainty for creditors as well as debtors and other parties.

The provisions stipulated in the Financial Services Authority Regulation Number 33 / Pojk.03/2018 concerning Earning Asset Quality and the Formation of Allowance for Earning Assets of Rural Credit Banks, that the Bank or the Rural Credit Bank as the creditor can do a takeover of the debtor's great authority that has been defaulted, with the conditions as mentioned above, then there will be legal consequences for both parties, both the debtor and the creditor. The existence of collateral conditions taken over in the form of and Declaration of Submission of guarantees from the debtor and the Paid Certificate from the Creditor cause legal consequences, in the form of the abolition of the debtor's rights to the goods used as collateral and also eliminate the debtor's obligations towards the loan facilities received from the creditor, due to the issuance of the certificate paid off, can result in the legal termination of credit agreement, as the principal agreement, While the fiduciary agreement is an accessoire agreement (an additional agreement from a credit agreement). The legal consequences caused to the creditor can execute collateral that is carried out by the debtor voluntarily by selling it under the hand or by auction in public and taking repayment of the debtor's obligations towards the loan given by the creditor. If the sale proceeds less than the debtor's obligations, it will be a loss for the creditor, whereas if it is more and becomes a profit for the creditor. So the debtor is no longer entitled to the excess of the sale. Whereas based on the provisions in the Act Number 42 of 1999 concerning Fiduciary guarantees, Article 34 paragraph 3 and paragraph 4, stipulates that, in the event that the execution results exceed the guarantee value, the Fiduciary Recipient must return the excess to the Fiduciary Giver and if the execution results are insufficient for debt repayment, the debtor remains responsible for the outstanding debt.

By using the theory of Norma (Stufenbau Theorie), and theory of Legal Certainty, and with the principle or principle of "lex superior derogat legi inferiori", according to researchers Financial Services Authority Regulation Number 33 / Pojk.03/2018 Concerning Earning Asset Quality and Formation of Asset Abolition Earning a Rural Bank, regulating the issue of Collateral Foreclosed can be set aside or become invalid, or at least a material test is conducted by the Supreme Court. If violated, it results in being null and void. In connection with this, there is no legal certainty, so that legal protection for debtors, who due to their financial condition is not possible to carry out obligations, in good faith to hand over their collateral to the creditor as the repayment of obligations is impossible. 
Legal Protection for Default Debtors for Fiduciary Credit Settlement.

By using the theory of legal protection, debtors who have defaulted in good faith to surrender the objects of fiduciary security they control voluntarily without any forced efforts from the debtor must obtain legal protection. Legal protection referred to herein is where the debtor surrenders the object of fiduciary collateral, by making a statement of the surrender of the guarantee to the creditor, whereas the creditor must make a statement in full on the debtor's obligations to the creditor. With the receipt of the fiduciary collateral object, the creditor can sell the fiduciary collateral object himself. If there is an excess of the proceeds from the sale of the debtor's obligations it will be a profit or income for the creditor, the debtor is no longer entitled to the excess. but on the contrary, if the sale proceeds of the fiduciary collateral submitted by the debtor are less than the debtor's obligations, then it becomes a loss for the creditor and the creditor can no longer charge the shortage to the debtor because the debtor has received a statement of credit from the creditor.

Based on the Constitutional Court Decision No. 18 / PUU-XVII / 2019, the Constitutional Court has changed the mechanism of execution of fiduciary guarantee objects as long as they are not voluntarily given by the debtor. When initially Law Number 42 of 1999 concerning Fiduciary Guarantees allows creditors to execute their own fiduciary collateral objects, as of 6 January 2020 the creditor must submit an execution request to the District Court (PN). However, execution without a District Court is still open if the debtor has acknowledged the existence of a broken promise in the credit agreement with the creditor. In cases like this, the debtor should voluntarily give the fiduciary object to the creditor. Assistance from the police is provided only with the excuse to maintain security and order in the execution process. Before the ruling of the Constitutional Court, the police had been involved in securing executions based on Police Chief Regulation No. 8/2011 concerning Security of Fiduciary Guarantee Execution. However, not to allow the police to withdraw fiduciary collateral objects from the debtor, but rather to ensure the security of the execution. Fiduciary, according to Law Number 42 of 1999, is the transfer of ownership rights of an object based on trust provided that the object whose ownership rights are transferred remains in the possession of the object owner. The object owner acts as the fiduciary giver (debtor), while the fiduciary recipient (creditor) is a party that has receivables for which payments are guaranteed with fiduciary collateral. A fiduciary guarantee certificate containing the identity of the fiduciary giver and recipient, description of the object, guarantee value, up to the value of the object and includes the phrase "For Justice Based on Almighty God" as a court ruling. Initially, Article 15 paragraph (2) of Law no. 42/1999 concerning Fiduciary regulates that fiduciary guarantee certificates have the same executorial power as court decisions that have obtained permanent legal force. Furthermore, Article 15 paragraph (3) of Law Number 42 Year 1999 states that the fiduciary recipient has the right to sell objects which are the object of fiduciary collateral for his own power if the debtor is injured. However, in the decision of the Constitutional Court explained that the material in Article 15 paragraph (2) of Law Number 42 Year 1999 does not provide legal certainty and justice for debtors. The reason is that creditors can execute fiduciary collateral objects without a court execution mechanism. The Court is of the opinion that unilateral action has the potential to cause arbitrary and inhumane actions both physically and psychic towards debtors who often override fiduciary rights. In addition to this, the Constitutional Court considers the unconstitutionality in Article 15 paragraph (3) of Law Number 42 Year 1999. The phrase "promise of injury" does not explain the factors that cause the fiduciary giver to deny the agreement with the fiduciary recipient.

Based on these considerations, the Constitutional Court re-interpreted the constitutionality of Article 15 paragraph (2) of Law 42 of 1999 on the phrase executive power and the same as a court decision that has obtained permanent legal force, so that against fiduciary guarantees for which there is no agreement on the injury of promise or breach of contract and debtors object to voluntarily surrendering the object of fiduciary guarantee, then all legal mechanisms and procedures in the implementation of the execution of the fiduciary guarantee certificate must be carried out and apply the same as the execution of a court decision that has permanent legal force. Meanwhile, the phrase "promise injury" in Article 15 paragraph (3) of the Fiduciary Guarantee Act must be 
interpreted as a promising injury is not determined unilaterally by the creditor but on the basis of an agreement between the creditor and the debtor or on the basis of legal efforts that determine the occurrence of the promise injury. After the Decision of the Constitutional Court Number 18 / PUU-XVII / 2019 of articles in the Fiduciary Law, particularly regarding Default and Execution of Fiduciary Guarantees, the interpretation has changed. The execution mechanism, which has so far been "not good" and it must be corrected. After the Constitutional Court Decision, default and execution must be interpreted differently. Defaults must be agreed upon and execution must have a voluntary statement from the debtor or through a court decision.

Settlement of defaults and execution of disputes through the court is considered ineffective, will cost a lot of time and time, and is not a solution to the achievement of justice from the debtor and creditor, because basically the debtor and creditor should respect the credit agreement that they have made as to the principal agreement, in this case, the fiduciary guarantee agreement which is ratified as a fiduciary deed. As mitigation of dispute resolution, both the debtor and creditor must understand the making of a fiduciary guarantee agreement which becomes a fiduciary deed. Here all aspects of its making must be seen, starting from the parties present, to the accuracy in making the editions of the agreement. There must be no loopholes used by irresponsible parties. At present, dispute resolution can be carried out as before the Constitutional Court Decision, if there is a default, then the execution of fiduciary object taking can be carried out voluntarily, only that all aspects of the law must be observed, not to have any law violated in carrying out the execution. The creditor if he wants to execute the debtor can also include the police, but for security purposes, it is not for execution. Then the dispute resolution depends on the Risk Appetite of each party, inevitably the most important thing is to ensure that all agreements are made referring to the existing regulations and carry out the execution by referring to the Fiduciary Law, which can be voluntary with the debtor's permission or through the court.

\section{CONCLUSIONS}

Based on the results obtained and discussed above, thus it can be concluded that 1) based on norm selection theory (Stufenbau Theorie) and legal certainty theory used as the analysis knife in this study by referring to the provisions set out in article 7 paragraph 1 of Law Number 12 of 2011 concerning Procedures for Establishing Invitations and with the principle or principle of "lex superior derogat legi inferiori", according to researchers Financial Services Authority Regulation Number 33 /Pojk.03/2018 Regarding Quality of Earning Assets and Formation of Allowance for Earning Assets of Rural Credit Banks, regulating the issue of Collateral Foreclosed can be overridden or become not valid, or at least a material test by the Supreme Court. If violated, it results in being null and void. 2) Based on legal protection theory, that Article 15 paragraph (2) of Law Number 42 Year 1999 does not provide legal certainty and justice for debtors. The reason is that creditors can execute fiduciary collateral objects without a court execution mechanism. The Court believes that unilateral actions have the potential to cause arbitrary and inhumane acts both physically and psychologically against debtors who often override the rights of fiduciary givers.

Grounded by the conclusion above, thus, it can be suggested that 1) the state in this case the government or other relevant institutions to conduct a material test of Article 34 paragraph 1 and paragraph 2 of Law Number 42 of 1999 with Article 27 Paragraph 3 of the Republic of Indonesia Financial Services Authority Regulation Number 33 / Pojk.03/ 2018 Concerning the Quality of Earning Assets and the Formation of Allowance for Earning Assets from Rural Credit Banks so that they can guarantee legal certainty and external legal protection for parties to settle problem loans with fiduciary guarantees. 2) In the settlement of problem loans, especially those using collateral with fiduciary binding as collateral for loans, the debtor and creditor should take the sale under the hand (nonlitigation), with the agreement of both parties by creating legal protection internally in a mutually determined agreement. 
REFERENCES

Ibrahim, J. (2004). Mengupas Tuntas Kredit Komersial dan Konsumtif dalam Perjanjian Kredit Bank (Perspektif Hukum dan Ekonomi). Bandung: Mandar Maju.

Ida, A., Nofrial, R., Anatami, D., Rahadian, R., \& Thaib, M. (2020). Legal Protection of Creditors and Debtors through Fiduciary Security Registration. IJRR: International Journal of Research and Review, 7(8), 352-360. Retrieved from https://www.ijrrjournal.com/ IJRR_Vol.7_Issue.8_Aug2020/Abstract_IJRR0044.html

Marzuki, P. M. (2009). Penelitian Hukum. Jakarta: Kencana Prenada Media Group.

Puspasari, R. M., \& Ngazis, M. (2021). Debtor Protection in the Execution of Fiducia Securities. Jurnal Pembaharuan Hukum, 8(1), 26. https://doi.org/10.26532/jph.v8i1.13798

Tahir, P. (2017). Legal protection for creditors towards credit guarantee in Indonesia. Scientific Research Journal (SCIRJ), 5(2), 12-16. Retrieved from http://www.scirj.org/2017/feb-2017paper. php? rp=P0217387

Waluyo, B. (2008). Penelitian Hukum dalam Praktek. Jakarta: Sinar Grafindo. 